\title{
Peningkatan Budaya Literasi melalui Kegiatan Pojok Baca di SD Muhammadiyah Plus Malangjiwan Colomadu
}

\author{
Panji Hidayatulloh ${ }^{1}$, Ayu Solihatul2), \\ Endah setyo ${ }^{3)}$, Rosita Husna Fanantya ${ }^{4}$, , Sekar Mustika Arum ${ }^{5)}$, Ririn Tri \\ Utami Nurul Istiqomah ${ }^{6)}$, Shandy Novilia Purwanti ${ }^{7)}$ \\ 1,2,3,4,5,6,7)Fakultas Keguruan dan Ilmu Pendidikan \\ Universitas Muhammadiyah Surakarta \\ 1)panjihidayatulloh@gmail.com \\ doi: $\mathrm{xxx} \operatorname{xxx} \mathrm{xxx}$
}

\begin{abstract}
Abstrak: Membaca menjadi hal yang penting dalam proses belajar mengajar..membaca merupakan proses penyerapan ilmu melalui suatu bacaan atau tulisan. Setiap siswa mempunyai kemampuan yang bervariasi dari yang cepat, sedang dan lambat dalam hal membaca.Penelitian ini bertujuan untuk meningkatkan Perlu adanya pembiasaan pada siswa dalam meningkatkan minat membaca.dengan diadakannya literasi diharapkan mampu menikatkan minat baca pada siswa dan menambah ilmu yang dapat menjadi bekal di masa yang akan datang di SD Muhammadiyah Plus Malangjiwan Colomadu. Obyek penelitian adalah Guru kelas beserta siswa kelas I-V dengan teknik pengumpulan data secara observasi langsung, wawancara dan dokumentasi. Data yang diperoleh dianalisis secara kualitatif menunjukan bahwa pertama kegiatan pojok baca merupakan progam evaluasi yang ada di SD Muhammadiyah Plus Malangjiwan. Kedua, Pelaksanaan kegiatan pojok baca dilakukan secara setiap hari.
\end{abstract}

Kata kunci : kegiatan literasi dengan pojok baca.

\section{Pendahuluan}

Membaca merupakan suatu kegiatan yang penting dalam proses belajar mengajar, karena membaca adalah kemampuan penyerapan suatu ilmu melalui teks atau bacaan. Kita dapat mengetahui suatu informasi dengan membaca, dan kita dapat menambah wawasan dan dapat berfikir secara kritis. Tanpa membaca, kita tidak bisa mengetahui apa yang terjadi di dunia, dan kita tidak dapat mengetahui ilmu-ilmu yang ada di dunia, maka dari itu membaca menjadi hal penting dalam pengetahuan dan belajar mengajar

Pada siswa SD budaya membaca perlu diadakannya proses pembiasaan. Pembiasaan itu sendiri merupakan proses membuat sesuatu yang menjadikan seseorang terbiasa, dalam kaitannya metode pengajaran dapat dikatakan bahwa pembiasaan adalah sebuah cara yang dapat dilakukan untuk membiasakan siswa berfikir. Kebiasaan membutuhan kegigihan dari seorang pembimbing.(Arief. 2004:110)

Sekolah Dasar Muhammadiyah Plus Malangjiwan memiliki suatu 
trobosan baru demi meningkatkan minat membaca dengan adanya pojok baca. Pojok Baca adalah suatu kegiatan yang dilakukan siswa disetiap waktu luang disela-sela jam pelajaran untuk membaca buku yang telah tersedia dirak pojok kelas. Pojok baca ini juga berlaku sebagai perpustakan mini yang terdapat disetiap kelas.

Fungsi dari adanya pojok baca itu sendiri yaitu untuk membiasakan siswa membaca buku. Selain itu juga sebagai salah satu program untuk membrantas kebodohan. Selain itu juga pojok baca berfungsi sebagai salah satu program untuk pengkondisikan siswa agar siswa tidak gaduh dikelas, setelah siswa selesai mengerjakan tugas yang diberikan guru maka sswa diperbolehkan membaca buku di daerah pojok baca sembari menunggu jam pelajaran selesai.

Adapun tujuan yang ingin dicapai dalam penelitian ini adalah untuk mendiskripsikan dan menganalisa adanya kegiatan perpustakaan kelas atau sering di sebut pojok baca yang merupakan progam unggulan di SD Muhammadiyah Plus malangjiwan colomadu serta yang berfungsi sebagai perbaikakan sistem pembelajaran dan peningkatan pengetahuan peserta didik. Penelitian ini juga dapat ditujukan untuk mahasiswa sebagai referensi tentang peningkatan budaya literasi dengan memanfaatkan pojok baca yang ada di SD Muhammadiyah Plus Malangjiwan sekaligus dapat mengembangkan minat menulis mahasiswa. Selain itu penelitian ini sebagai salah satu syarat memenuhi mata kuliah magang 1 .

\section{Metode}

\section{a. Objek Penelitian}

Objek dalampenelitian ini adalah seluruh siswa SD Muhammadiyah

Plus Malangjiwan Colomadu

b. Tempat dan Waktu Pelaksanaan

Tempat: SD Muhammadiyah Plus Malangjiwan Colomadu

Karanganyar Waktu : 2 minggu

\section{c. Jenis Penelitian}

Jenis penelitian yang digunakan yaitu penelitian deskriptif. Penelitian deskriptif dikaitkan dengan persoalan tujuan penelitian. Pemecahan masalah yang ada pada masa sekarang merupakan suatu hal yang ditju dari penelitian ini. Tujuan penelitian ini adalah menggambarkan secara tepat sifat-sifat suatu individu, keadaan, gejala, atau kelompok tertentu. Penelitian ini juga memiliki 2 ciri pokok yaitu memusatkan perhatian pada masalah-masalah yang bersifat penting, dan menggambarkan fakta-fakta tentang masalah yang diselidiki sebagaimana yang diiringi dengan interpretasi rasional. Penelitian deskriptif pada umumnya dikumpulkan melalui dokumentasi, wawancara, dan observasi. .(Muchamad Ridho Hidayat). 
Penelitian ini akan mendeskripsikan konsep, faktor pendukung dan faktor penghambat, tentang pojok baca untuk seluruh siswa di SD Muhammadiyah Plus Malangjiwan Colomadu.

\section{d. Teknik Pengumpulan Data}

Pengumpulan data yang diterapkan sebagai alat pengumpulan data dalam penelitian ini adalah :

1) Observasi

Observasi yaitu dasar dari semua ilmu pengetahuan. Semua orang dapat bekerja berdasarkan data, yaitu fakta mengenai dunia kenyataan yang diperoleh melalui observasi. Data dikumpulkan dengan bantuan berbagai alat yang sangat canggih, sehingga bendabenda yang sangat kecil maupun yang sangat jauh dapat diobservasi dengan jelas. (Sugiyono. 2012: 226).

Kegiatan dalam penelitian ini dilakukan dalam bentuk observasi dengan tujuan untuk mengetahui seberapa besar antusiasme siswa dengan adanya kegiatan pojok baca di SD Muhammadiyah Plus Malangjiwan Colomadu.

2) Wawancara

Wawancara yaitu pertemuan dua orang untuk bertukar informasi dan ide melalui tanya jawab, sehingga dapat dikontruksikan makna dalam suatu topik tertentu. (Sugiyono. 2012: 231). Pada penelitian ini wawancara dilaksanakan dengan responden yakni guru kelas untuk mengetahui implementasi perpustakaan kelas dan faktor - faktor pendukung serta penghambat dalam proses kegiatan belajar mengajar pada siswa di SD Muhammadiyah Plus Malangjiwan Colomadu.

3) Metode Dokumentasi

Metode dokumentasi digunakan untuk mendapatkan data yang berupa portofolio, arsip, rekaman, dan laporan siswa. Dokumen merupakan catatan peristiwa yang sudah berlalu (Sugiyono. 2012:241). Dalam dokumentasi ini digunakan untuk mengabadikan hasil - hasil penelitian untuk memperlancar proses pembuatan laporan.

\section{e. Teknik Analisis Data}

Teknik analisis data menggunakan teknik analisis kualitatif. Analisis data kualitatif yaitu suatu metode penelitian yang berlandaskan pada filsafat positive, yang digunakan untuk meneliti pada kondisi objek yang alamiah, yang dimana peneliti merupakan sebagai instrument kunci, dari pengambilan sampel sumber data yang dilakukan dengan cara purposive dan snowbaal, teknik pengumpulan trianggulasi, analisa data secara induktif dan kualitatif, dan hasil penelitian kualitatif lebih menekan pada makna dan generalisasi. (Sugiyono) 
Teknik analisis data kualitatif menggunakan konsep yang diberikan Miles and Hubermen. Miles dan Hubermen dalam Sugiyono (2005: 91), mengemukakan bahwa aktivitas dalam analisis data kualitatif dilakukan secara interaktif dan berlangsung secara terus menerus sampai tuntas, sehingga datanya sudah jenuh. Aktivitas dalam analisis data yaitu data reduction, data display, dan conclution drawing/verivication.

Analisis data penelitian ini diawali pengumpulan data yang diperoleh dari observasi dan wawancara. Data yang diperoleh dari observasi dan wawancara kemudian diolah dengan tahap penyuntingan, pengkodean, dan tabulasi. Data yang dihasilkan dapat diambil melalui metode kualitatif yang menghasilkan data deskriptif. Setelah data diolah maka data dapat didisplay secara tersusun dalam pola hubungan. Kemudian menarik kesimpulan pada data yang telah didisplay. Jadi melalui teknik inilah dapat diketahui sejauh mana siswa mampu mengimplementasikan kegiatan pojok baca untuk seluruh siswa di SD Muhammadiyah Plus Malangjiwan Colomadu.

Setelah data dianalisis dan dilakukan penafsiran, maka hasil penelitian dapat disimpulkan. Penarikan kesimpulan dari implementasi pojok baca untuk seluruh siswa di SD Muhammadiyah Plus Malangjiwan Colomadusesuai dengan hasil yang ada dilapangan.

\section{Hasil dan Pembahasan}

Budaya membaca merupakan suatu kegiatan yang penting dalam proses belajar mengajar, karena membaca adalah kemampuan penyerapan suatu ilmu melalui teks atau bacaan. Kita dapat mengetahui suatu informasi dari kegiatan membaca, dan kita dapat menambah wawasan serta dapat berfikir secara kritis.

Rendahnya tingkat partisipasi peserta didik dalam kegiatan membaca membuat salah satu Sekolah Dasar di daerah karanganyar tepatnya di SD Muhammadiyah Plus Malangjiwan menerapakan budaya membaca yakni dengan diadakannya kegiatan Pojok baca yang telah berjalan kuarang lebih setahun belakangan ini, kegiatan ini diadakan di setiap kelas yang bertujuan untuk meningkatkan budaya membaca pada anak, yang pada era milenial ini anak maupun orang dewasa lebih suka membaca pada gadged dari pada buku, sehingga pihak sekolah berinisiatif untuk menerapakan kegiatan pojok baca. Kegiatan pojok baca tersebut sudah berjalan degan baik meskipun belum maksimal, karena ada beberapa kendala, diantaranya masih ada beberapa anak yang jarang melakukan kegiatan tersebut jika tidak disuruh langsung oleh gurunya,yang kedua kurangnya buku referensi yang tersedia masih sedikit sehingga terkadang tak jarang ada siswa yang sudah membaca semua buku yang tersedia di pojok baca tersebut. Sekolah juga menawarkan apabila ada pihak lain yang 
mau menghibahkan buku meraka yang tidak terpakai kepada kami untuk menambah fasilitas buku di pojok baca, tak jarang terkadang siswa juga membawa buku dari rumah yang sudah tidak terpakai untuk di hibahkan disekolah. Buku yang dibacapun tak selalu tentang pendidikan berbagai refrensi lain yang tidak ada sangkut pautnya dengan pendidikan juga mereka baca, karena pojok baca ini bertujan untuk meningkatkan budaya membaca pada siswa dan menambah wawasan yang luas dengan membaca buku tersebut.

Setiap sebulan sekali terkadang ada kegiatan rolling buku pada setiap kelas supaya buku yang mereka baca lebih banyak lagi, untuk tempat pojok bacanya itu sendiri siswa juga menghias tempat pojok baca tersebut dan dibantu oleh guru pandamping supaya tempat pojok baca tersebut terlihat indah dan menarik sehingga menjadikan siswa lebih semangat untuk membaca buku.

Dengan adanya pojok baca semua siswa dari kelas rendah sampai kelas atas mulai terbiasa mandiri dan mau membaca buku tanpa disuruh oleh gurunya, meskipun pada awalnya guru agak susah untuk mengajak siswa membaca. Namun Pojok baca ini memiliki kelebihan dan kekurangan. Kelebihan dari pojok baca ini yaitu dapat mengoptimalkan waktu luang untuk membaca buku, siswa tidak perlu jauh-jauh ke perpustakaan, tanpa menunggu perintah dari guru untuk membaca buku ketika ada waktu luang atau ketika sudah selesai mengerjakan tugas siswa berinisiatif untuk membaca buku di pojok baca. Pojok baca juga memiliki kekurangan yaitu perpustakaan sekolah akan menjadi sepi, kurangnya koleksi buku yang berada di kelas, kurangnya koordinasi pada saat pertukaran buku antar kelas, dapat membuat ruang kelas menjadi lebih sempit, masih rendahnya kesadaran siswa untuk menjaga dan menata buku perpustakaan kelas.

\section{Simpulan}

Membaca merupakan suatu kegiatan yang penting dalam proses belajar mengajar, karena membaca adalah kemampuan penyerapan suatu ilmu melalui teks atau bacaan. Kita dapat mengetahui suatu informasi dengan kegiatan membaca, dan kita dapat menambah wawasan serta dapat berfikir secara kritis. Tanpa membaca, kita tidak bisa mengetahui apa yang terjadi di dunia, dan kita tidak dapat mengetahui ilmu-ilmu yang ada di dunia, maka dari itu membaca menjadi hal penting dalam pengetahuan dan belajar mengajar.

Sekolah Dasar Muhammadiyah Plus Malangjiwan memiliki suatu terobosan baru demi meningkatkan minat membaca dengan adanya pojok baca. Pojok Baca adalah suatu kegiatan yang dilakukan siswa disetiap waktu luang disela-sela jam pelajaran untuk membaca buku yang telah 
tersedia dirak pojok kelas. Pojok baca ini juga berlaku sebagai perpustakan mini yang terdapat disetiap kelas. Pojok baca ini berfungsi untuk membiasakan siswa membaca buku. Selain itu juga sebagai salah satu program untuk memberantas kebodohan. Selain itu juga pojok baca berfungsi sebagai salah satu program untuk mengondisikan siswa agar tidak gaduh dikelas, setelah siswa selesai. Buku-buku yang melengkapi perpustakaan kelas ini terdiri atas buku pengetahuan umum, buku pelajaran, buku cerita, komik, buku keagamaan, novel dan kumpulan cerpen.

Pojok baca ini memiliki kelebihan dan kekurangan. Kelebihan dari perpustakaan kelas ini yaitu dapat mengoptimalkan waktu luang untuk membaca buku, siswa tidak perlu jauh-jauh ke perpustakaan, tanpa menunggu perintah dari guru untuk membaca buku ketika ada waktu luang atau ketika sudah selesai mengerjakan tugas siswa berinisiatif untuk membaca buku di pojok baca. Selain kelebihan pojok baca juga memiliki kekurangan yaitu perpustakaan sekolah akan menjadi sepi, kurangnya koleksi buku yang berada di kelas, kurangnya koordinasi pada saat pertukaran buku antar kelas, dapat membuat ruang kelas menjadi lebih sempit, masih rendahnya kesadaran siswa untuk menjaga dan menata buku perpustakaan kelas. Kegiatan pojok baca tersebut seduah berjalan dengan baik dan panatas mendapatkan apresiasi meskipun belum maksimal, namun pihak sekolah terus berbenah dalam hal tersebut sehingga tujuan dari di bentuknya pojok baca tersebut dapat tercapai dengan maksimal.

\section{Daftar Pustaka}

Usman, Husaini dan Purnomo Setiady Akbar. 2009. Metodologi Penelitian Sosial. Jakarta: Bumi Aksara.

Bungin, Burhan. 2001. Metodologi Penelitian Sosial : Format-format kuantitatif dan kualitatif. Surabaya: Airlangga University Press.

Sugiyono. 2012. Metode Penelitian Kuantitatif, Kualitatif, dan R\&D. Cetakan ke-17. Bandung: Alfabeta.

Sukardi, M. 2008. Evaluasi Pendidikan Prinsip dan Operasionalnya. Jakarta: Bumi Aksara.Nurkancana, Wayan dan Sumartana, P.P.N. 1983. Evaluasi Pendidikan. Surabaya: Usaha Nasional.

Arikunto, Suharsimi. 2010. Dasar-Dasar Evaluasi Pendidikan. Jakarta: Bumi Aksara. 